\title{
The Microphysics of Participation in Refugee Research
}

\section{GIORGIA DONÁ}

\author{
Refugee Research Centre, University of East London Docklands Campus, \\ 4-6 University Way, London E16 2RD \\ g.dona@uel.ac.uk
}

\begin{abstract}
This paper examines the involvement of refugees in the production and reproduction of knowledge of which they are ultimately meant to be beneficiaries. By using examples from research with Central American refugees and Rwandan displaced children, it considers forced migrants' roles as participants in research, their position in 'participatory' research, and the representation of refugees' voices in refugee-centred research. Power is intimately connected to the diverse ways in which participation unfolds, and the last part of the paper examines refugees' participation in research in terms of 'power that circulates' (Foucault) to show that they are not more or less powerful but vehicles for the circulation of power, simultaneously undergoing and exercising it.
\end{abstract}

Keywords: refugee participation, participatory research, representation, refugee voices, Foucault's power, Central American refugees, Rwandan children

\section{Introduction}

Forced migration ${ }^{1}$ researchers implicitly or explicitly embrace the ideal that the knowledge they generate will ultimately help the uprooted and displaced: research into the suffering of others can only be justified if alleviation of that suffering is an explicit objective, Turton wrote in 1996 (p. 96). The preoccupation with forced migration researchers to contribute to social change has been noticeable since the institutionalization of the field of refugee studies (Stein and Tomasi 1981; Zetter 1988) and continues to be present (Gingrich 2002; Black 2001; Jacobsen and Landau 2003). As such, forced migration research is 'partisan', rather than neutral, to the plight of the subjects of its investigation: studying the experiences, causes and consequences of displacement is done with the implicit or explicit intent to influence the development of better policies and programmes on the part of governments, non-governmental and inter-governmental agencies and refugee community organizations. 
Given this general orientation of refugee studies, it is reasonable to ask what role and involvement forced migrants themselves have in the process of creation, codification, and reproduction of knowledge of which they are ultimately meant to be beneficiaries. Questioning participation and representation is not confined to forced migration research; it is the topic of discussions across disciplines.

In social science research, the term 'participation' refers to a wide range of involvements, ranging from answering questions to becoming co-researchers (e.g. Christiansen and Prout 2002). In development studies, discussions on participation revolve around the adoption of 'participatory methodologies' whose goals are the increased involvement of beneficiaries, the valuing of local knowledge and the promotion of social change through the active engagement of participants (Chambers 1994b). In social and educational sciences 'participatory action research', situated within critical pedagogy or critical sciences, similarly denotes research whose explicit aim is to promote awareness and social change from below (Freire 2003; Fals Borda and Rahaman 1991; Miskovic and Hoor 2006; Reason and Bradbury 2001).

More broadly conceived, participation refers to citizenship rights and democracy in political sciences (Habermas 1989), is articulated as the inclusion of 'subjugated knowledges' in philosophy and sociology (Foucault 1980), and is concerned with issues of representation: of the ethnographer as the narrator of another culture in anthropology (Abu-Lughod 2006; Clifford and Marcus 1986), of gender in mainstream research (Wolf 1992; Indra 1999), and of the 'Other' in critical literary theory and post-colonial studies (Said 2000).

Given that one distinctive feature of refugee studies is its interdisciplinary nature, how do these debates inform the way in which scholars in the field understand and subscribe to 'participation' as a methodology? In this paper I take a broad view of participation that includes the analysis of participation as a method and as an approach. To examine how 'participation' is conceptualized and operationalized in forced migration research, I review three subject areas that, based on my analysis of the refugee literature, are significant: the role of refugees as 'participants' in refugee research, their involvement in 'participatory' research, and their representation through 'refugees' voices'. Power pervades these areas, and the last section of the paper examines the relationship between power and participation through the 'circulation of power' (Foucault 1980). It shows that refugees, researchers and manifold other participants in refugee research are vehicles of power, not its points of application, across complex and dynamic net-like systems.

\section{'Participants' in Refugee Research}

The noun 'participation' can have a variety of meanings, ranging from 'taking part' or being present to 'knowing that one's actions are taken note of and may be acted on, sometimes called empowerment' (Boyden and Ennew 1997: 33). Borrowing from Christiansen and Prout's typological 


\section{Giorgia Doná}

description of child participation in social science research (2002), it is possible to view refugees' involvement in forced migration research as follows: objects, subjects, social actors, and participants and co-researchers. They are 'objects' when their lives and experiences are investigated from the perspective of others such as government officials, aid workers, lawyers or receiving societies' members, or when they are symbolically present as 'objects' of study in disciplines such as legal theory or international relations that deal with institutional and legal frameworks. As 'objects', they have no power over the creation or production of knowledge about them.

They are 'subjects' when their involvement in the research process is limited to that of respondents who answer questions developed by others, and where they have very limited power over the research process apart from deciding what information to convey or retain. They can be 'social actors' who can make sense of their lives and research when they are in dialogue with the researcher and inform the content of the research process not simply as respondents to pre-determined questions but as informants knowledgeable about their experiences. They are 'participants and co-researchers' when they are involved, informed, consulted, and heard, within the new social sciences methodologies that see research as a co-production of knowledge (Christiansen and Prout 2002). An analogy can be drawn to refugees' predicaments in life where they may be objects of government policies, subjects to welfare provisions, social actors and/or co-researchers in social movements, advocacy groups, non-governmental and refugee community organizations.

\section{'Documented' and 'Undocumented' Participants}

This typology is somewhat static and restrictive and does not capture the complex network of those involved or the dynamic relationships that occur and evolve during research. In refugee studies, there is an emerging interest to consider, discuss and disseminate the acquired methodological knowledge and experience. Although not unique to refugee research, indeed similar to research with vulnerable groups, ethnic communities, or on sensitive topics, among others (Curtis et al. 2004; Nilan 2002; Pain and Francis 2003; Valentine et al. 2001), dissemination of reflexive knowledge is generating overt methodological discussions about the specific challenges and insights of conducting research with refugees.

Bloch (1999), Jacobsen and Landau (2003), and Tyldum and Brunovskis (2005) for instance identify specific challenges when conducting survey research with refugees in the UK, urban refugees in South Africa and trafficked people in Norway: how are samples selected when sampling frames are lacking; what are the challenges of gaining access to hidden populations; what is the role of interviewers, interpreters and local researchers; what security and confidentiality issues surface; and what are the constraints of working in unfamiliar environments? The authors agree 
that while there is no one best practice, knowledge of the target cohort and use of multiple gatekeepers, consideration of methodological and ethical concerns, and development of estimates would advance the study of forced migrants.

Methodological challenges and examples of participants' involvement in roles other than those of respondents have been described by MacMullin and Loughry (2000) for Palestinian refugee children who were involved in developing and administering questions to other children, by Doná (2006) who compared two research projects in which separated children in Rwanda and Bangladesh acted as research advisors, and by Dyregrov et al. (2000) who documented refugee families' experiences of research participation.

Kosygina (2005), Hynes (2003) and Miller (2004), among others, examine important issues surrounding relationships between researchers and forced migrants. Kosygina (2005) argues that mutual gender categorizations influence both the quality of information obtained and the techniques themselves. Her interviews with forced migrants from other republics of the Former Soviet Union into Russia varied in length, format and degree of reflexivity depending on whether she was interviewing men or women, and in the case of male migrants, whether they were young or old. Hynes (2003) examines the history and relationships of mistrust that accompany the refugee experience, and argues that making a space for trust should be regarded as a priority by researchers, agencies and those who work with refugees. Similarly, drawing on examples from his research with refugees from Guatemala, Bosnia and Afghanistan, Miller (2004) utilizes Goffman's metaphor of frontstage and backstage behaviour to illustrate the importance of developing relationships of trust that enable 'backstage' access, essential if researchers want to gather data that accurately reflects the authentic beliefs and experiences of refugee communities that are likely to have developed selfprotective insularity. Miller also points to the puzzling lack of discussion surrounding trust, relational contexts and access in the literature on refugee mental health, and attributes it to the prevailing scientific paradigm that shapes the values of those he describes as the field 'gatekeepers', editors and reviewers of scholarly journals.

An example from my research shows how these diverse aspects interrelate. In a study aimed at investigating the relationship between acculturation attitudes and mental health of Central American refugees in Canada (Doná and Berry 1994), I used survey questions on acculturation and health that had been tested with diverse acculturating groups, and which I revised, translated and back-translated with the aid of a Latin American nurse, Paz, herself a refugee. The last part of the questionnaire contained information about health risks and it included a few questions on exposure to violence, including a question on torture. When I piloted the questionnaire, all those interviewed replied negatively to the question on exposure to torture. By speaking with Paz I indirectly learnt that one of the participants I had previously interviewed had been subjected to torture. This information 


\section{Giorgia Doná}

prompted me to question the sensitivity of the information I was asking, which I considered health-related (scientific and neutral), but that could have been and possibly was perceived as political, sensitive or intimate. It also brought into light the importance of establishing trust and familiarity, both of which were limited in my relationships with the interviewees but which grew in my relationship with Paz, the unofficial participant, and helped to reshape the direction of the study.

More generally, this example raises the question of who counts as 'participant'. Unofficial participants may contribute as much intellectual input or information as official respondents or co-researchers. They too shape the content or methodology of a study but remain peripheral or invisible in the main text, their contribution at most accredited in the acknowledgements. Yet, they are part of a net-like system that includes manifold kinds of 'documented' and 'undocumented' participants including: those involved in pilot studies to ensure that questionnaires are reliable, gatekeepers who facilitate access and may effectively select who participates and who does not, interviewees, interviewers, interpreters, and research assistants. They may be refugees themselves, migrants, members of the national or ethnic group researched, may share a language, be local researchers. Their role in the research process is vital yet unobserved.

The increased interest among forced migration researchers to publish information about the challenges and insights encountered while conducting research with refugees contributes to the increased knowledge on specific methodological issues of refugee research. Rather than portraying static and discrete categorizations of refugees as objects or subjects, they point to the existence of multiple kinds of participants, to the many roles they may assume, and to the network of relationships that develop and evolve in the process of knowledge generation. In the section on power at the end of the paper, I will show how power circulates in these net-like systems. In the next section, I will explore the involvement of participants when the aim is to conduct research for social change.

\section{'Participatory Research' with Refugees}

Intrinsically linked to the term participation is the adjective 'participatory', which in social sciences and development studies has come to define a distinctive approach to research, which is collaborative and aims to achieve social change from below. For Cornwall and Jewkes (1995), the distinction between participatory and conventional methodologies lies less in the theories or even the methods used but in who defines research problems or generates, analyses, represents, owns and acts on the information that is sought. Chambers's (1994a, b, c) work on Participatory Rural Appraisal (PRA) has contributed to the widespread popularity of participatory research in development, which he describes as 'a family of approaches and methods to enable local (rural and urban) people to express, enhance, share and 
analyse their knowledge of life and conditions, to plan and to act' (1994b: 1253). In reality, 'participatory research' refers to a wide range of practices ranging from merely confirming results with a target population after research has been conducted, to engaging beneficiaries from the start in developing conceptual ideas, and to solution identification and subsequent implementation of chosen answers (Rutta et al. 2005).

Participatory research is advocated because the development of policies and practices based on research with intended beneficiaries is more likely to meet their needs and interests, and interventions that are based on local knowledge and experience are more likely to be relevant and sustainable (Kothari 2001). Some kind of participation is generally advocated by agencies that work with forced migrants. The Sphere Project Standards (2004) for instance acknowledges the importance of participation of disaster-affected populations in the assessment, design, implementation, monitoring and evaluation of assistance programmes, while UNHCR has embraced 'people-oriented planning' (Anderson 1994).

More specifically, Rutta et al. (2005) describe the collaborative efforts by several agencies to develop a generic field guide to analyse refugees' views of healthcare services for Burundian and Rwandan refugees in camps. Kaiser (2004) reflects on a 'beneficiary based' evaluation of UNHCR's programme for Sierra Leonean and Liberian refugees in camps in Guinea, and raises the question of whether it is feasible to carry out a truly participatory evaluation of a refugee programme that has not itself been participatory in its planning and implementation. Outside camps, Sullivan et al. (2004) describe the launch of a programme aimed at improving reproductive health services and building clinic capacity at the Mae Tao clinic in Thailand, which provides health services for illegal migrant workers and displaced people from Burma. An evaluation of the participatory approach used to monitor and evaluate the programme showed that people's feelings of ownership improved and that staff became motivated to collect and use data for programme decision-making.

As the examples above indicate (see also Chatty et al. 2005; Kibreab 1999; Lykes 1997; Tanaka et al. 2004), much 'participatory research' with refugees (mostly conducted in contexts of assistance or development) would belong to what Hickey and Mohan call the 'populist/participation in development' approach (2005: 240), where participation is required to empower people, capture indigenous peoples' knowledge and ensure sustainability and efficiency of interventions. This approach focuses on participation in projects rather than in broader political communities, and can be described as programmatic rather than transformative.

Hickey and Mohan (2004) criticize the assumption that transformations in power relations between 'uppers' and 'lowers' can be achieved through the simple involvement of beneficiaries at each stage of intervention when it fails to engage with issues of power and politics raised by the language of 'empowerment', while Cornwall and Brock (2005) criticize the mainstreaming 


\section{Giorgia Doná}

of concepts like 'participation' and 'empowerment' by major organizations and funding bodies, whose appropriation has transformed terms that spoke of politics and power into a-politicized buzzwords, one-size-fits-all, which everyone can agree with. Programmatic participation is valuable but less controversial than transformative participation; it is useful to improve a programme in camps through the involvement of beneficiaries but more controversial if their involvement in 'participatory research' led to challenging the very existence of camps, or their temporary nature, or the presence of humanitarian workers.

Kothari (2001) offers a different kind of analysis. She criticizes participatory discourses for creating a number of binaries between lowers and uppers, south and north, local knowledge and professional knowledge that set up dichotomous oppositions invested of moral authority (the first term of the dichotomy being 'good' and the second 'bad'), where the aim of participatory work is to reverse them. She writes that in this way the micro is set against the macro, the margins against the centre, the local against the elite, and the powerless against the powerful. The focus on the micro-level, on people who are considered powerless and at the margin tends to reproduce the simplistic notion that the sites of social power and control are to be found solely at the macro-centre levels. As McNay argued, if participatory approaches are to be bottom-up and uncover the daily oppression in people's lives, their interests and needs, they need to go beyond conventional stratifications of power to explore the micro-points of power.

'To understand power, therefore, it is necessary to analyse it in its most diverse and specific manifestations rather than focusing on its most centralized forms such as its concentration in the hands of a coercive elite or a ruling class. This focus on the underside of everyday aspect of power relations Foucault calls a microphysics rather than a macrophysics of power' (McNay 1994: 3, in Kothari 2001: 143-144).

\section{The Microphysics of 'Participatory' Research}

Indeed, an analysis of the microphysics of 'participatory' research with refugees highlights the many sites of power and its diverse manifestations. Kaiser (2004) identifies challenges to refugee participation in the relations that these may have with aid workers or host government representatives, and which include scepticism as to whether refugees can engage straightforwardly in participatory processes due to fear of losing material assistance, risks to informants, or resistance on the part of refugees' hosting governments.

Boyden (2001) observes that children's participation in contexts of forced migration, as a rule, is highly restricted. She begins her paper by pointing out that most research is about refugees in camps but that in real terms most refugees seek privacy and invisibility outside camps, and then goes on to 
describe reasons why child participation may be challenging. These reasons point to the many locations of power and its manifestations. Child participation may be absent for cultural or other reasons to start with; rural communities may resist participation of children in contexts of mobility where traditional inter-generational relations are undermined. As refugee communities emerge out of crisis, they are frequently made up of individuals who do not share common origins, with fractured family relations and together by accident, making participation a complex endeavour. Furthermore, relations tend to be highly politicized in communities of forced migrants, and information of any kind, however neutral it may on the surface appear, can be seen as dangerous. Also, with no agency, host country, nor the migrant population wishing to conceive of refugee measures as being long term, there is no motivation to develop those kinds of planning and structures that are required to foster participation. Finally, conceptual barriers to children's participation include perceptions of vulnerability and incapacity of children in relationships to adults.

A microphysics analysis of the lives of forced migrants outside camps indicates that urban refugees, undocumented migrants, dispersed asylum seekers, invisible refugees, integrated refugees do not inhabit separate physical or social spaces that can be changed without negotiations with other groups; more importantly, they do not necessarily imagine bounded or shared social environments to be improved, making participatory research challenging.

Furthermore, the awareness in refugee studies that the term 'refugee', rather than being a marker of socio-cultural identity, shared past or common vision for a future, has become identified with legal definitions or administrative labels (Zetter 1991; Farbey 2002) under which diverse individuals are subsumed, means that it is complex to disentangle who are the participants in 'participatory research'. Participatory research with 'refugees' is a multifaceted undertaking. Participatory research with the 'refugee community' (Anderson's imagined community, enclosing all refugees) is an essentializing practice if the term refugee is used as a label; participatory research 'with refugees' involved in projects translates as programmatic participation. Participatory research with refugee advocacy groups or refugee community organizations, when it incorporates aspiration for broader political changes, direct advocacy work or social transformation may become transformative participation. Interestingly, most criticisms of 'participatory research' are vocalized with the aim of improving, not discarding participation (e.g. Boyden 2001; Hickey and Mohan 2004; Kaiser 2004; Parfitt 2004). An analysis of its workings at the microphysics level may be one way of enhancing it.

From an 'advocacy' or policy oriented standpoint, if 'participatory research' with forced migrants aims to achieve social change, it is likely to benefit by being embedded in broader processes of social transformations. In development studies, Hickey and Mohan (2004) have recently suggested that 'participation in development' should be relocated within a 'radical 


\section{Giorgia Doná}

politics of development', where this is pursued as part of a political project, aimed at securing citizenship rights, and where it engages with development as an underlying process of social change rather than in the form of discrete technocratic interventions. It is challenging to translate these ideals to contexts of forced migration, often characterized by the de facto de-politicization of refugees (as traumatized, victims, or in need), by loss of citizenship rights, and ambivalence towards social changes. Would it be possible to envision that 'participatory research' with refugees be re-located within a 'radical politics of migration, asylum and protection': to envisage undocumented migrants, asylum seekers, internally displaced and refugees participating in the development of asylum, migration and assistance policies and practices?

\section{Refugees' Voices, Refugee-centred Research, and Refugee Studies: Endeavours in Representation}

'Participation' can also refer to the inclusion of refugees' voices, experiences and perspectives in the creation and representation of knowledge. In the first issue of the Journal of Refugee Studies (1988) the then editor Roger Zetter concluded his inaugural editorial as follows:

We thus come full circle to the final and perhaps most important objective. Those best able to define, explain and promote an understanding of the parameters which govern their lives are the refugees themselves within and from both host countries and refugee communities. JRS will actively encourage publication of material in this genre, especially by refugees. We wish to give expression to their voices as much as to their existence as research data, and to their stories as much as their abstraction as cases (p. 6).

'Refugee voices' find expression in accounts of refugees' personal or group experiences of persecution and displacement (e.g. Said 2000; Baker 1989); they are allocated distinct space in the Refugee Voice section of the Journal of Refugee Studies (e.g. Flores-Borquez 1995; Kumsa 2006) and are brought together by initiatives like the Exile Writers Ink project in London, UK. Autobiographical narratives, life histories, and self-reflective analyses are the chosen medium to represent one's own experience of exile or that of one's group. Baker (1989), for instance, narrates his escape from German persecution and journey to the United Kingdom as an unaccompanied minor who grew up in a foster family, became a psychologist and works with refugees.

Complementary to the direct involvement of refugees in both creation and dissemination of narratives, the phrase 'refugees' voices' is also used to refer to the many contributions that focus on refugees' experiences, that include quotes or extracts of interviews with refugees, or that represent refugees' viewpoints. Here researchers develop a coherent story from diverse narratives told by participants, with the goal of representing their voices, adopting what 
is usually referred to as a refugee-centred or refugee-focused perspective. Many articles in the Journal of Refugee Studies can be classified as being of this type. It is worth pointing out that legal, administrative and policy papers based on analysis of documents are also refugee-centred when they represent refugees' viewpoints as opposed to those of nation-states, governments or other agencies.

I consider my research with Guatemalan refugees living in settlements in Mexico an example of refugee-centred research. My aim was to listen to the refugees and to convey their experiences (Doná and Berry 1999; Doná and Ackermann 2006) rather than those of the aid workers living with them in the camps, the Mexicans living in neighbouring villages or the Mexican, UNHCR, or Guatemalan authorities. These other groups were of interest but indirectly, as they were seen through the eyes of the Guatemalan refugees or in their relations to them. While living in the settlements, I occasionally visited the Mexican villages neighbouring the camps and informally conversed with their inhabitants, but I did not systematically research their views.

When I visited the Guatemalan refugees after their return to Guatemala, I became aware of the network of relations interweaving together returnees, internally displaced, and those who had stayed behind, and of the benefit of striving to simultaneously adopt multiple refugee-centred perspectives, which don't necessarily converge. For instance, while in Mexico Guatemalan refugees referred to Guatemalan internally displaced as 'brothers' and emphasized the similarity in their histories of persecution and displacement, upon return, when competing for resources, differences emerged, expressed through the language of development (more or less developed).

In addition to these kinds of refugee-centred perspectives, there are those where refugees speak simultaneously about themselves and their group. Kumsa's (2006) study on the poetics of be-longing among young Oromos in Canada is a fascinating example of the intersection between complementary 'refugee-centred perspectives'. Guided by the principles of critical inquiry, Kumsa sets out her work by positioning her researcher Self and the participant Other. An Oromo journalist born in Ethiopia and a strong advocate of Oromo liberation, she, herself was forced to flee after having spent ten years in prison as a prisoner of conscience. Embarking on a doctoral dissertation was 'as much about the producing and reproducing knowledge as it is about constructing and reconstructing Self' (2006: 232).

\section{Refugee Studies: Endeavours in Representation}

A substantial body of forced migration research can be recognized as being refugee-centred, refugee-oriented, or refugee-focused in its theoretical and methodological orientation. The desire to promote a comprehensive, historical, interdisciplinary and comparative perspective which focuses on the consistencies and patterns in the refugee experience' (Stein and 
Tomasi 1981: 6, italics added) was a key objective of those initial efforts to found the new field of Refugee Studies.

Refugee Studies then can be seen as an endeavour in methodological and conceptual representation; it is (mainly though not exclusively) about representing refugee experiences/voice(s). Representation can refer to 'speaking of' - constructing accounts and writing texts - or it can mean 'speaking for'-advocating and mediating. In this respect Refugee Studies would resemble the work of the Subaltern Studies Group that combined the two in the belief that by speaking of the subaltern experience they would change the political relations in their favour (Mohan 2001).

Refugee Studies as an endeavour in representation has been at least partially successful. Within academia, the study of refugees has challenged anthropologists to revisit assumptions about their work, as exemplified by Davis's (1992) 'anthropology of suffering'. Refugee-centred perspectives have also contributed to the improvement of individual programmes and policies, though the extent and long-term impact is unclear. Black (2001) identifies participatory and gender-sensitive approaches, and environmental awareness, as two areas in which refugee-focused perspectives have made an impact, although partial, since the development of strong links between research and policy has often failed to translate into significant policy changes. Chimni (1998) highlights the key role of UNHCR in refugee knowledge production and dissemination, albeit a neglected one. With the goal of bridging the gap between refugee research and practice, UNHCR has promoted a working paper series on 'New Issues in Refugee Research' and set up an internal Evaluation and Policy Analysis Unit, which operates on the principles of consultation, in addition to those of 'transparency, independence, relevance and integrity' (UNHCR 2002a: 4).

Issues of representation are central to the alleviation of suffering and critical to efforts refugees make to improve their lives. Those seeking protection and assistance continuously rely on lawyers, case workers, interpreters, aid workers, governmental and non-governmental organizations and campaigning groups to represent them in their claim for asylum, to get aid, to fund-raise for projects, and to advocate for social and political changes.

Representation implies the presence of a physical or symbolic entity that acts as advocate, 'bears witness', makes visible. McGovern (2006) identifies four types of representation: descriptive, instrumental, personalist and managerial. Descriptive representation relies on the corresponding resemblance between the represented and the representative: this is best evident in the case of the Refugee Voice described at the beginning of this section. Instrumental representation relies on 'acting on behalf of' and best captures the work of narrators of refugee experiences and those who adopt a refugeecentred perspective. Personalist representation is concerned with corresponding personal attributes, values and orientations between the represented and the representative: refugee researchers who strive to conduct research with the 
ultimate goal of improving the lives of refugees can be said to carry a general orientation corresponding to that of refugees. Finally, managerial representation is based on tasks, programmes and agendas, as seen in research conducted to improve specific programmes. This typology helps to identify general consistencies and patterns but it does not address issues surrounding the 'crisis of representation' that permeates social sciences, and possibly Refugee Studies.

\section{Binary Logics and Interstices}

Questions of representation have been the subject of methodological and theoretical reflexivity for a while. Clifford and Marcus (1986) instigated discussions on representation within anthropology while the diffusion of interpretative methodologies has led to the explicit analysis of relationships of representation (Nilan 2002), including those of feminists and 'halfies'-people whose national or cultural identity is mixed (Abu-Lughod 2006). Forced migration researchers have generally been in tune with methodological debates taking place within their own disciplines (positionality, sampling, researching sensitive groups, cross-validation) and have relied on them to address specific methodological challenges in their research with refugees (Ahearn 2000; Krulfeld and MacDonald 1998; Temple and Moran 2006).

In forced migration research, it is acknowledged that the interests of refugees and asylum-seekers may not be represented by the primarily middleclass, elite, and often white European research community, and that the claims of different groups may themselves compete (Black 2003). There is uneasiness with the binary distinction between experts and refugees (MacDonald 1998; Kumsa 2006). Titling the first editorial 'Refugees and refugee studies: a label and an agenda', Zetter (1988) raises different issues of representation: can a label be represented, and if so how? Labels can be used to simplify the social world but they are not neutral.

In forced migration studies, there seems to be a propensity to represent refugees in essentialist ways, the hegemony of trauma as the major articulation of refugee suffering being an example of such essentialist representation (Bracken et al. 1997; Eastmond 1998). Furthermore, there is a propensity to represent refugees through a binary (often oppositional) logic: victim/survivor, resilient/vulnerable, bogus/genuine, regular/irregular, displacement/emplacement, rooted/uprooted, deserving/undeserving, healthy/ ill, outside/inside, asylum seeker/citizen, problem/resource, etc., highlighting the pervasive influence of Cartesian dualism in our western mode of thinking.

Said (1978) and Escobar (1984/1985), among others, have shown how the framing of knowledge happens through the implicit and explicit construction of binary opposites: Europe/Orient; self/other; north/south; developed/ underdeveloped. Similarly, Grossberg (1996) identifies the existence of models of binary opposition, like the 'colonial' model of the oppressor/ oppressed and the 'transgression' model of oppression/resistance. He criticizes 


\section{Giorgia Doná}

such binary classifications, and suggests that they be replaced by a model of 'transformative practice'. In Orientalism, Said called for the elimination of 'the Orient' and 'the Occident' altogether, but by this he did not mean the erasure of all differences but the recognition of more of them and of the complex ways in which they crosscut.

In a similar direction, Bhabha (1994) challenged binary classifications and introduced the concept of 'interstices' to describe situations in-between, which forced migrants would inhabit. Examining the emergence of social crises sparked off by histories of cultural difference such as the Los Angeles riots among Ladinos and Asians, Bhabha writes:

It is in the emergence of the interstices - the overlap and displacement of domains of difference - that the intersubjective and collective experience of nationness, community interest, or cultural values are negotiated. How are subjects formed 'in-between', or in excess of, the sum of the 'parts' of difference (usually intoned as race/class/gender etc.)? How do strategies of representation or empowerment [italics added] come to be formulated in the competing claims of communities where, despite shared histories of deprivation and discrimination, the exchange of values, meanings and priorities may not always be collaborative and dialogical, but may be profoundly antagonistic, conflictual and even incommensurable? (1994: 2).

Shifts from essentializing and binary categorizations towards multiplicity, transformative practices and negotiations as suggested by Said, Grossberg and Bhabha may help to revisit current approaches to representation in Refugee Studies. Said would challenge the essentialized construction of the Refugee as the Other, Grossberg the propensity to rely on models that propose binary constructs (victim/survivor) while Bhabha would invite us to move beyond the existing boundaries that define refugee-centred research (in our minds as members of the 'community of refugee studies scholars') into what he calls the interstices, what lies in between, or in excess of the sum of the parts of difference that possibly shape refugee research, ethnic research, gender research, poverty research and so on.

\section{Power and Participation: Interconnectedness and Circulation}

Connecting the various ways in which participation is understood is the concept of power: 'whether we are talking about nonexploitative methodology in field research or authority in writing ethnography, we are talking about power-who has it, how it is used, for what purposes' (Wolf 1992: 133). The relationship between participation and power could at first be described as being correlational or incremental: the involvement of socially disadvantaged and vulnerable groups is sought because it will hopefully lead to greater social inclusion and empowerment; 'participatory research' is advocated because it promotes empowerment and social change. Similarly, 'refugee-centred' research is concerned with the representation of refugee 
voices/perspectives in ways that promote refugees' views and challenge nation-centric ones. However, the examples given in the paper point to a more complex analysis, where many kinds of participants, systems and representations interrelate.

Hardy et al. (2001) describe the interconnectedness, dynamism and integration among various systems that deal with refugees as 'social' subjects and as 'research' subjects. Adopting an actor-network theory, they consider the net-like systems of actors (governments, non-governmental organizations and refugee community organizations) involved in the production of the 'social subject' - the refugee, and draw a parallel with the integrated systems of actors, researchers and the research community (peer reviews, journals, etc.) involved in the production of the 'research subject'-the refugee as a subject of academic inquiry. Within and across these systems, as Foucault writes, power circulates:

Power must be analysed as something which circulates, or rather something which only functions in the form of a chain. It is never localized here or there, never in anybody's hands, never appropriated as a commodity or piece of wealth. Power is employed and exercised through a net-like organization. And not only do individuals circulate between its threads: they are always in the position of simultaneously undergoing and exercising this power. They are not only its inert or consenting targets; they are always also the elements of its articulation. In other words, individuals are the vehicles of power, not its points of application (1980: 98).

Foucault's notion of power as something that circulates overcomes essentialist, static and binary notions, and in this respect, it shares the multiplicity, dynamism and fluidity of the analyses proposed by Said, Grossberg and Bhabha.

Foucault's insights into the workings of power have been used to understand refugees' predicaments in general. Hardy (2003) investigated the dynamics of power in refugee determination systems in three countries to challenge the view that determination systems function according to rational decision-making processes and are an instrument of the State. Hendrie (1997) employed it to analyse a famine relief operation with Tigrayan refugees in eastern Sudan in 1984/1985, and showed that certain discourses on 'famine' led to the dominance of certain kinds of institutional practices. Triantafillou and Nielsen (2001) examined two empowerment projects for women and showed that the recasting of empowerment from its usual meaning of transfer of power to a Foucauldian analysis of technologies of power, unveils that it seeks to create self-governing and responsible individuals in the western liberal democracy sense.

Foucault's microphysics of the circulation of power is also valuable to rethink 'participation' in refugee research, and I will use the example of a research project in which I participated to explore some of its dimensions. As international consultant hired by Unicef to lead a team of researchers in a 


\section{Giorgia Doná}

study on foster care arrangements for displaced and separated children in post-genocide Rwanda (Doná 2001), I was given power (circulation officially began) at the moment of signing the contract. The research team for the project, a joint initiative of Unicef, the Rwandan Government and Radda Barnen, worked in consultation with two advisory groups, one composed of representatives of relevant agencies, and another of children representing both fostered children and children in other types of care arrangements (living with extended families, in child-headed households, etc.). The 'official' participants of the study were fostered children, foster parents, foster and natural siblings, non-governmental social workers and government staff, all of whom were individually interviewed or invited to participate in group discussions.

By taking on the role of project leader, I exercised power over the research team as their technical supervisor and line manager. The fact that I had previously worked with two of the researchers for two years and known them for four years when living in Rwanda meant that circulation of power had begun well before the project officially started. If during the research I exercised power when leading technical discussions about the research methodology, I was simultaneously subjected to the power of the Rwandan researchers who decided which sites to visit and selected families to be interviewed, and they in turn were subjected to the power of local representatives or non-governmental workers who facilitated access. Research assistants interpreted for me, translated interviews, and helped to give meaning and context to the information collected, hence exercising power over the flow of information.

On more than one occasion I felt that power was circulating away from me when I was on my own on a Rwandan hill with only a basic knowledge of Kinyarwanda, while Rwandan villagers watching me probably thought of me as the one exercising power. I may have held power over the interpreters by guiding the choice of topics I wanted to investigate but I was simultaneously subjected to their power of conveying what I said and interpreting responses; whenever I recognized the meaning of an occasional Kinyarwanda word, I felt power briefly circulating through me again.

As interviewers, we may have exercised power over a fostered child but we were also simultaneously subjected to her power of deciding what to tell or conceal, and generally to the power of fostered children as without their voices we would have not been in a position to have a study on foster care. In writing the final report, I may have exercised power over the development of the written output but I was also simultaneously subjected to the power of the advisory committees, the UN, the Rwandan Government and nongovernmental agencies, which were going to decide which, if any, of the proposed recommendations would be implemented, or to what extent.

Researchers, interpreters, collaborators, interviewees, advisors, and gatekeepers are not more or less powerful but are vehicles of power in a net-like organization. In the study on foster care, power constantly circulated 
among the research team, the two advisory committees, key informants, participants and many other systems. Not only were there continuous translations to and from Kinyarwanda, French and English but most significantly parallel translations and back-translations between academic, non-governmental, governmental and UN 'languages'. In the course of the research, different discourses on fostering, accompanied by distinct institutional practices, surfaced. Government discourses reflected the position 'one child one family': separated children should be placed with a family; those of non-governmental organizations working with fostered children revolved around 'best fostering practices'; and those of Unicef focused on 'child rights'. Our task was to interpret and integrate these discourses, so that others could use them. In this process, the research team became one of many organizations in a net-like system, and was a vehicle for the circulation of power.

The example above has linked together issues separately raised in previous sections. In thinking about who participates in knowledge production, it confirms the presence of many official and unofficial 'participants', while the analysis of the microphysics of power circulation shows that stakeholders hold different aspirations for social change, and that diverse representations of children coexisted.

\section{Conclusion}

In this paper, I have attempted simultaneously to describe the various ways in which 'participation' can be conceptualized, and to problematize it. The paper brought together subjects that are usually either examined in detail in specific studies, or treated discretely in the literature. I conceptualized participation in terms of its technical aspects (e.g choice of participants) as well as more broadly to refer to the meaning of 'participant', to collaboration and social change, and inclusion of refugees' voices in Refugee Studies.

The first three sections of the paper-participants, participatory research and refugee-centred research - were chosen because of their relevance for a conceptual discussion of 'participation' in refugee studies (based on my reading of the forced migration literature). Each section began with a description of discrete or static classifications and moved on to highlight the complex and dynamic nature of 'participation'. The section on 'participants' moved from a classification of participants as objects, subjects, social actors and co-researchers to the description of manifold kinds of official and unofficial participants interconnected in net-like systems. The section on 'participatory research' began with a definition of this type of research as collaborative research for social change and then developed an analysis of the microphysics of collaborations and sites of powers. The section on inclusion of refugee-centred perspectives pointed to the tendency to rely on binary representations of 'refugees' voices', and suggested ways to move beyond them. 
Refugee Studies seems to have reached a stage of 'maturity': an increasing amount of information is available to enable a critical engagement with methodological self-reflexivity about specific challenges, insights and general orientations underpinning research with refugees. It is timely to explore the role of 'undocumented' participants in research and how multiple identities coexist among participants simultaneously belonging to the research and researched groups. The interdisciplinary nature of forced migration studies means that researchers benefit from dialogue across disciplinary boundaries, and this could include self-reflexive methodological discussions of crossdisciplinary collaborations in refugee research.

The application of Foucault's analysis of the microphysics of power to participation in refugee research was instrumental in showing how power circulates in research. This enables refugees and researchers, amongst others, to 'reclaim' a different relation to power and participation. Rather than conceiving power as something which is possessed or incremental, the view that power is something which circulates places all 'participants'-refugees, researchers, interpreters, interviewees, and so on-on an equal footing: they are vehicles for the circulation of power, simultaneously undergoing and exercising it.

1. The terms 'refugee' and 'forced migrant' are used interchangeably in the paper.

ABU-LUGHOD, L. (2006) 'Writing against Culture', in Lewin, E. (ed.) Feminist Anthropology: A readers, Oxford: Blackwell.

AHEARN, F. L. Jr. (ed.) (2000) Psychological Wellness of Refugees: Issues in Qualitative and Quantitative Research, Oxford: Berghahn.

ANDERSON, M. B. (1994) People-oriented Planning at Work: Using POP to Improve UNHCR Programming, Geneva: UNHCR.

BAKER, R. (1989) 'The Refugee Experience: Communication and Stress, Recollection of a Refugee Survivor', Journal of Refugee Studies 3: 64-72.

BHABHA, H. K. (1994) The Location of Culture, London: Routledge.

BLACK, R. (2001) 'Fifty Years of Refugee Studies: From Theory to Politics', International Migration Review 35(1): 57-78.

BLACK, R. (2003) 'Breaking the Convention: Researching the "Illegal" Migration of Refugees to Europe', Antipode 35(1): 34-54.

BLOCH, A. (1999) 'Carrying out a Survey with Refugees: Some Methodological Considerations and Guidelines', Journal of Refugee Studies 12(4): 367-383.

BOYDEN, J. (2001) 'Children's Participation in the Context of Forced Migration', Participatory Learning and Action 42: 52-56.

BOYDEN, J. and ENNEW, J. (1997) Children in Focus: A Manual for Participatory Research with Children, Sweden: Report for Radda Barnen.

BRACKEN, P., GILLER, J. E. and SUMMERFIELD, D. (1997) 'Rethinking Mental Health Work with Survivors of Wartime Violence and Refugees', Journal of Refugee Studies 10(4): 431-442.

CHAMBERS, R. (1994a) 'The Origins and Practice of Participatory Rural Appraisal', World Development 22(7): 953-969. 
CHAMBERS, R. (1994b) 'Participatory Rural Appraisal (PRA): Analysis of Experience', World Development 22(9): 1253-1268.

CHAMBERS, R. (1994c) 'Participatory Rural Appraisal (PRA): Challenges, Potential and Paradigm', World Development 22(10): 1437-1454.

CHATTY, D., CRIVELlO, G. and HUNDT, G. L. (2005) 'Theoretical and Methodological Challenges of Studying Refugee Children in the Middle East and North Africa: Young Palestinians, Afghans, and Sahrawi Refugees', Journal of Refugee Studies 18(4): 387-409.

CHIMNI, B. S. (1998) 'The Geopolitics of Refugee Studies: A View from the South', Journal of Refugee Studies 11(4): 350-374.

CHRISTENSEN, P. and PROUT, A. (2002) 'Working with Ethical Symmetry in Social Research with Children', Childhood 9(4): 477-497.

CLIFFORD, J. and MARCUS, G. (1986) Writing Culture: The Poetics and Politics of Ethnography, Berkeley: University of California Press.

CORNWALL, A. and BROCK, K. (2005) 'What do Buzzwords do for Development Policy? A Critical Look at "Participation", "Empowerment" and "Poverty Reduction", Third World Quarterly 26(7): 1043-1060.

CORNWALL, A. and JEWKES, R. (1995) 'What is Participatory Research?' Social Science and Medicine 41(12): 1667-1676.

CURTIS, C., ROBERTSON, H., COPPERMAN, J., DOWNIE, A. and LIABO, C. (2004) 'How Come I Don't Get Asked No Questions? Researching "Hard to Reach" Children and Teenagers', Child and Family Social Work 9: 167-175.

DAVIS, J. (1992) 'The Anthropology of Suffering', Journal of Refugee Studies 5(2): 149-161.

DONÁ, G. (2001) The Rwandan Experience of Fostering Separated Children, Stockholm, Sweden: Save the Children.

DONÁ, G. (2006) 'Children as Research Advisors: Contributions to a "Methodology of Participation" in Researching Children in Difficult Circumstances', International Journal of Migration, Health and Social Care 2(2): 22-34.

DONÁ, G. and ACKERMANN, L. (2006) 'Refugees in Camps', in Sam, D. and Berry, J. W. (eds), Cambridge Handbook of Acculturation Psychology, Cambridge: Cambridge University Press.

DONÁ, G. and BERRY, J. W. (1999) 'Refugee Acculturation and Re-acculturation', in Ager, A. (ed.) Refugees: Current Issues and Directions. London: Continuum.

DONÁ, G. and BERRY, J. W. (1994) 'Acculturation Attitudes and Acculturative Stress of Central American Refugees in Canada', International Journal of Psychology 29(1): 57-70.

DYREGROV, K., DYREGROV, A. and RAUNDALEN, M. (2000) 'Refugee Families' Experience of Research Participation', Journal of Traumatic Stress 13(3): 413-426.

EASTMOND, M. (1998) 'National Discourses and the Construction of Difference: Bosnian Muslim Refugees in Sweden', Journal of Refugee Studies 11(2): 161-181.

ESCOBAR, A. (1984/1985) 'Discourse and Power in Development: Michel Foucault and the Relevance of his Work to the Third World', Alternatives 10: 377-400.

FALS BORDA, O. and RAHAMAN, M. (1991) Action and Knowledge: Breaking the Monopoly with Participatory Action Research, London: Intermediate Technology Publication.

FARBEY, J. (2002) 'The Refugee Condition: Legal and Therapeutic Dimensions', in Papadopoulos, R. K. (ed.) Therapeutic Care for Refugees: No Place like Home, London: Karnac.

FLORES-BORQUEZ, M. (1995) ‘A Journey to Regain my Identity', Journal of Refugee Studies 8(1): 95-109.

FOUCAULT, M. (1980) Power/Knowledge: Selected Interviews and other Writings 1972-1977, New York: Harvester Wheatsheaf.

FREIRE, P. (2003) Pedagogy of the Oppressed, New York: Continuum.

GINGRICH, A. (2002) 'Anthropological Approaches to Understanding Refugees', in Binder, S. and Tošić, J. (eds), Refugee Studies and Politics: Human Dimensions and Research Perspectives, WIEN: WUV: WEBA. 


\section{Giorgia Doná}

GROSSBERG, L. (1996) 'Identity and Cultural Studies: Is That all There is?', in Hall, S. and Du Gay, P. (eds), Questions of Cultural Identity, London: Sage.

HABERMAS, J. (1989) Structural Transformation of the Public Sphere, Cambridge, MA: MIT Press.

HARDY, C. (2003) 'Refugee Determination: Power and Resistance in Systems of Foucauldian Power', Administration and Society 35(4): 462-488.

HARDY, C., NELSON, P. and CLEGG, S. (2001) 'Reflexivity in Organization and Management Theory: A Study of the Production of the Research "Subject"', Human Relations 54(5): 531-560.

HENDRIE, B. (1997) 'Knowledge and Power: A Critique of an International Relief Operation', Disasters 21(1): 57-76.

HICKEY, S. and MOHAN, G. (eds) (2004) Participation: From Tyranny to Transformation? Exploring new Approaches to Participation in Development, London: Zed Books.

HICKEY, S. and MOHAN, G. (2005) 'Relocating Participation within a Radical Politics of Development', Development and Change 36(2): 237-262.

HYNES, T. (2003) The Issue of Trust or Mistrust in Research with Refugees: Choices, Caveats, and Considerations for Researchers, Working Paper 98. Geneva: UNHCR.

INDRA, D. (ed.) (1999) Engendering Forced Migration: Theory and Practice, Oxford: Berghahn.

JACOBSEN, K. and LANDAU, L. (2003) Researching Refugees: Some Methodological and Ethical Considerations in Social Science and Forced Migration, Working Paper 90. Geneva: UNHCR.

KAISER, T. (2004) 'Participation or Consultation? Reflections on a "Beneficiary Based" Evaluation of UNHCR's Programme for Sierra Leonean and Liberian Refugees in Guinea, June-July 2000', Journal of Refugee Studies 17(2): 185-204.

KIBREAB, G. (1999) 'The Consequences of Non-participatory Planning: Lessons from a Livestock Provisions Project to Returnees in Eritrea', Journal of Refugee Studies 12(2): $135-160$.

KOSYGINA, L. V. (2005) 'Doing Gender in Research: Reflection on Experience in the Field', The Qualitative Report 10(1): 87-95.

KOTHARI, U. (2001) 'Power, Knowledge and Social Control in Participatory Development', in Cooke, B. and Kothari, U. (eds), Participation: The New Tyranny? London: Zed Books.

KRULFELD, R. M. and MACDONALD, J. L. (eds) (1998) Power, Ethics, and Human Rights: Anthropological Studies of Refugee Research and Action, Oxford: Rowman \& Littlefield.

KUMSA, M. K. (2006) 'No I'm not a Refugee! The Poetics of Be-longing among Young Oromos in Toronto', Journal of Refugee Studies 19(2): 230-255.

LYKES, R. (1997) 'Activist Participatory Action Research among the Maya of Guatemala: Constructing Meanings from Situated Knowledge', Journal of Social Issues 54(4): 725-746.

MACDONALD, J. L. (1998) 'We are the Experts: Iu-Mien (Yao) Refugees Assert Their Rights as Scholars in their Own Culture', in Krulfeld, R. M. and MacDonald, J. L. (eds), Power, Ethics, and Human Rights: Anthropological Studies of Refugee Research and Action, Oxford: Rowman \& Littlefield Publishers.

MACMULLIN, C. and LOUGHRY, M. (2000) 'A Child-centered Approach to Investigating Refugee Children's Concerns', in Ahearn, F. L. Jr. (ed.) Psychosocial Wellness of Refugees: Issues in Qualitative and Quantitative Research, New York: Berghahn Books.

McGOVERN, J. B. (2006) 'Social Sciences and Political Representation', Paper presented at the Group for the Study of International Social Science, University of East London, May.

McNAY, L. (1994) Foucault: A Critical Introduction, London: Polity Press.

MILLER, K. E. (2004) 'Beyond the Frontstage: Trust, Access, and the Relational Context in Research with Refugee Communities', American Journal of Community Psychology 33(3/4): 217-227.

MISKOVIC, M. and HOOR, K. (2006) 'Action-research Meets Critical Pedagogy: Theory, Practice and Reflection', Qualitative Inquiry 12(2): 269-291. 
MOHAN, G. (2001) 'Beyond Participation: Strategies for Deeper Empowerment', in Cooke, B. and Kothari, U. (eds), Participation: The New Tyranny? London: Zed Books.

NILAN, P. (2002) 'Dangerous Fieldwork Re-examined: The Question of Researcher Subject Position', Qualitative Research 2(3): 363-386.

PAIN, R. and FRANCIS, P. (2003) 'Reflections on Participatory Research', Area 35(1): 46-54.

PARFITT, T. (2004) 'The Ambiguity of Participation: A Qualified Defence of Participatory Development', Third World Quarterly 25(3): 537-556.

REASON, P. and BRADBURY, H. (2001) Handbook of Action Research: Participatory Inquiry and Practice, London: Sage.

RUTTA, E., WILliamS, H., MWANSASU, A., MUNGONGO, F., BURKe, H., RAMADHANI, G., RWEGISERA, V. and MOHAMMED, Q. (2005) 'Refugee Perceptions of the Quality of Healthcare: Findings from a Participatory Assessment in Ngara, Tanzania', Disasters 29(4): 291-309.

SAID, E. (1978) Orientalism, New York: Pantheon.

SAID, E. (2000) Reflections on Exile and other Literary Essays, London: Granta.

SPHERE PROJECT STANDARDS (2004) Humanitarian Charter and Minimum Standards in Disaster Response (revised edition), www.sphereproject.org/handbook/hdbkpdf/hdbk.c5pdf.

STEIN, B. and TOMASI, L. (1981) 'Foreword', International Migration Review 15(1-2): 5-7.

SUlLIVAN, T. M., MAUNG, C. and NAW, S. (2004) 'Using Evidence to Improve Reproductive Health Quality along the Thailand-Burma Border', Disasters 28(3): 255-268.

TANAKA, Y., KUNII, O., OKUMURA, J. and WAKAI, S. (2004) 'Refugee Participation in Health Relief Services during the Post-emergency Phase in Tanzania', Public Health 1118(1): 50-61.

TEMPLE, B. and MORAN, R. (eds) (2006) Doing Research with Refugees: Issues and Guidelines, London: Policy Press.

TRIANTAFILlOU, P. and NIELSEN, M. R. (2001) 'Policing Empowerment: the Making of Capable Subjects', History of the Human Sciences 14(2): 63-86.

TURTON, D. (1996) 'Migrants and Refugees', in Allen, T. (ed.) In Search of Cool Ground: War, Flight and Homecoming in Northeast Africa, Trenton, NJ: Africa World Press.

TYLDUM, G. and BRUNOVSKIS, A. (2005) 'Describing the Unobserved: Methodological Challenges in Empirical Studies on Human Trafficking', International Migration 43(1/ 2): $17-34$.

UNHCR (2002) HIV/AIDS and Refugees: UNHCR's Strategic Plan 2002-2004. Geneva: UNHCR.

VALENTINE, G., BUTLER, R. and SKELTON, J. (2001) 'Ethical and Methodological Complexities of Doing Research with "Vulnerable" Young People', Ethics, Place and Environment 4(2): 119-124.

WOLF, M. (1992) A Thrice-told Tale: Feminism, Post-modernism and Ethnographic Responsibility, Stanford: University of Stanford Press.

ZETTER, R. (1988) 'Refugees and Refugee Studies: A Label and an Agenda', Journal of Refugee Studies 1(1): 1-6.

ZETTER, R. (1991) 'Labelling Refugees: Forming and Transforming a Bureaucratic Identity', Journal of Refugee Studies 4(1): 39-62.

MS received August 2006; revised MS received February 2007 